\title{
NUMERICAL SOLUTION OF THE PROBLEM OF BEAM ANALYSIS WITH THE USE OF B-SPLINE FINITE ELEMENT METHOD
}

\author{
Pavel A. Akimov 1, 2, 3, 4, Marina L. Mozgaleva ${ }^{1}$, Taymuraz B. Kaytukov ${ }^{1}$ \\ ${ }^{1}$ National Research Moscow State University of Civil Engineering, Moscow, RUSSIA \\ ${ }^{2}$ Tomsk State University of Architecture and Civil Engineering, Tomsk, RUSSIA \\ ${ }^{3}$ Peoples' Friendship University of Russia, Moscow, RUSSIA \\ ${ }^{4}$ Russian Academy of Architecture and Construction Sciences, Moscow, RUSSIA
}

\begin{abstract}
Numerical solution of the problem of beam analysis (bending analysis of the Bernoulli beam) with the use of B-spline finite element method is under consideration in the distinctive paper. The original continual and finite element formulations of the problem are given, some actual aspects of construction of normalized basis functions of a B-spline are considered, the corresponding local constructions for an arbitrary finite element are described, some information about the numerical implementation and an example of analysis are presented.
\end{abstract}

Keywords: wavelet-based finite element method, B-spline finite element method, finite element method, B-spline, numerical solution, beam analysis

\section{ЧИСЛЕННОЕ РЕШЕНИЕ ЗАДАЧИ О ПОПЕРЕЧНОМ ИЗГИБЕ БАЛКИ НА ОСНОВЕ ВЕЙВЛЕТ-РЕАЛИЗАЦИИ МЕТОДА КОНЕЧНЫХ ЭЛЕМЕНТОВ С ИСПОЛЬЗОВАНИЕМ В-СПЛАЙНОВ}

\author{
П.А. Акимов ${ }^{1,2,3,4}$, М.Л. Мозгалева ${ }^{1}$, Т.Б. Кайтуков ${ }^{1}$ \\ ${ }^{1}$ Национальный исследовательский Московский государственный строительный университет, \\ г. Москва, РОССИЯ \\ ${ }^{2}$ Томский государственный архитектурно-строительный университет, г. Томск, РОССИЯ \\ ${ }^{3}$ Российский университет дружбы народов, г. Москва, РОССИЯ \\ ${ }^{4}$ Российская академия архитектуры и строительных наук, г. Москва, РОССИЯ
}

\begin{abstract}
Аннотация: В настоящей статье рассматривается численное решение задачи о поперечном изгибе балки Бернулли на основе вейвлет-реализации метода конечных элементов с использованием В-сплайнов. Приведены исходные континуальная и конечноэлементная постановки задачи, рассмотрены некоторые актуальные вопросы построения нормализованных базисных функций В-сплайна, описаны соответствующие локальные построения для произвольного конечного элемента, представлены некоторые сведения о численной реализации и пример расчета.
\end{abstract}

Ключевые слова: вейвлет-реализация метода конечных элементов, метод конечных элементов, В-сплайны, численное решение, изгиб балки

\section{INTRODUCTION}

As is known, the B-spline in a given simple knot sequence can be constructed by employing piecewise polynomials between the knots and joining them together at the knots [1].
Compared with commonly used Daubechies wavelets [2-6] B-spline wavelet on interval (BSWI) has explicit expressions, facilitating the calculation of coefficient integration and differentiation [1]. Besides, the multiresolution and localization properties of BSWI can also supply some superiority for engineering 
structural analysis [1]. The early applications of spline can be found, for instance, in papers of $\mathrm{H}$. Antes [7], J.G. Han [8, 9, 25], Y. Huang [8, 9], W.X. Ren [8, 9]. The spline wavelet finite element method was further developed in papers of D.P. Chen [26], X.F. Chen [10, 11, 13-16, 21, 22, 24], H.B. Dong [21], J.G. Han [23], Y.M. He [15], Z.H. He [16], Z.J. He [10, 11, 13-15, 21, 22, 24], Y. Huang [23, 25], Z.S. Jiang [20], B. Li [11, 13, 15, 21], M. Liang [17, 19], J.Q. Long [18], G. Ma [18], T. Matsumoto [18, 20], S.T. Mau [28], H.H. Miao [13], Q,M. Mo [16], T.H.H. Pian [26-28], K.Y. Qi [21], W.X. Ren [23, 25], K. Sumihara [27], P. Tong [28], Y.W. Wang [20], J.W. Xiang [10-12, 15-20], Z.B. Yang [13, 14, 22], X.W. Zhang [14, 22, 24], Y.H. Zhang [10], Y.T. Zhong [12].

The distinctive paper is devoted to numerical solution of the problem of beam analysis (bending analysis of the Bernoulli beam) with the use of B-spline finite element method.

\section{FORMULATIONS OF THE PROBLEM}

The unknown function of the beam deflections $y(x)$, caused by the load $q(x)$, can be defined using the condition for the minimum energy functional of the beam $\Phi(y)$ (i.e. unknown function provides a minimum value for this functional):

$$
\Phi(y)=\frac{1}{2} \int_{0}^{l}\left[E J\left(y^{\prime \prime}\right)^{2}+\beta y^{2}\right] d x-\int_{0}^{l} q(x) y d x,
$$

where $E J(x)$ is the bending stiffness of the beam; $\beta$ is the coefficient of elasticity of the base (coefficient of bedding); $q(x)$ is the given load; $l$ is the length of the beam; $x$ is coordinate along the length of the beam. Let us divide the interval $[\mathrm{o}, l]$, occupied by the beam into $N_{e}$ parts (elements); $h_{e}=l / N_{e}$ is the length of the element. Let us also divide each element into $\mathrm{N}_{k}$ parts, for example, $N_{k}=5$ (Figure 1). Let us introduce the following notation system: $i_{e}$ is the element number; $x_{1}\left(i_{e}\right)$ is the coordinate of the starting point; $x_{6}\left(i_{e}\right)$ is the coordinate of the end point of the element number $i$, respectively. We take $y_{i}$ and $y_{i}^{\prime}$ as unknowns at boundary points $i=1,6$. We take $y_{i}, i=2,3,4,5$ as unknowns at the inner points. Thus, the number of unknowns per element with such discretization is defined by formula

$$
N=N_{k}-1+2 \cdot 2=N_{k}+3=8 .
$$

The number of boundary points for all elements is equal to

$$
N_{b}=N_{e}+1 \text {. }
$$

The number of interior points for all elements is equal to

$$
N_{p}=N_{e}\left(N_{k}-1\right) .
$$

The total (global) number of unknowns with such a discretization turns out to be equal to

$$
N_{g}=N_{p}+2 N_{b}
$$

Thus, we have

$$
\begin{gathered}
\Phi(y)=\sum_{i_{e}=1}^{N_{e}} \Phi_{i_{e}}(y) \\
\Phi_{i_{e}}(y)=\frac{1}{2} \int_{x_{1}\left(i_{e}\right)}^{x_{5}\left(i_{e}\right)}\left[E J\left(y^{\prime \prime}\right)^{2}+\beta y^{2}\right] d x-\int_{x_{1}\left(i_{e}\right)}^{x_{5}\left(i_{e}\right)} q y d x
\end{gathered}
$$

\section{SOME ASPECTS OF THE CONSTRUCTION OF NORMALIZED BASIS FUNCTIONS OF THE B-SPLINE}

The construction of B-spline basic functions is determined by the recursive Cox-de Boer formulas:

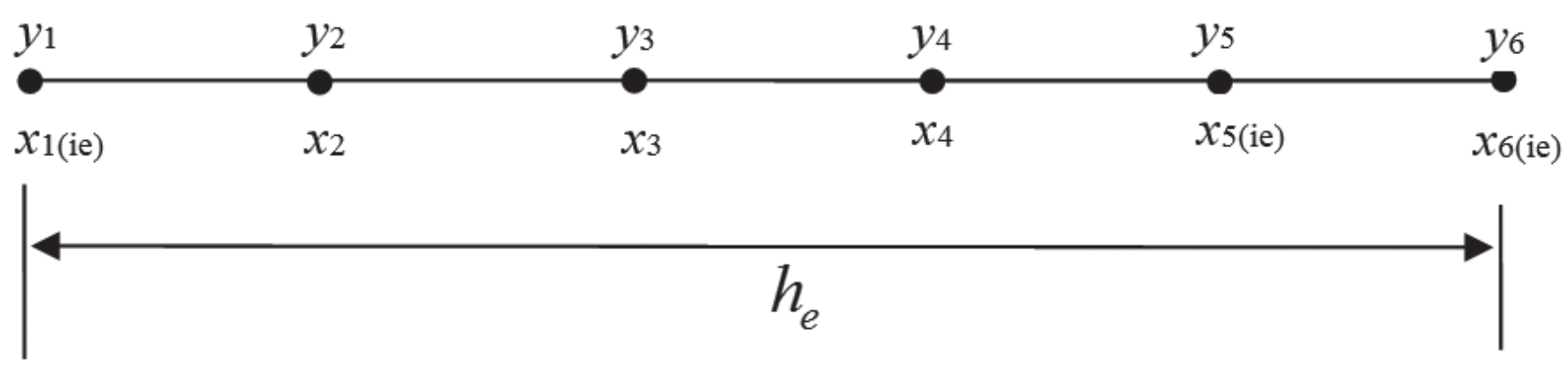

Figure 1. Finite element discretication (sample). 


$$
\begin{aligned}
k=1: \quad \varphi_{i, 1}(t)= & \left\{\begin{array}{l}
1, \quad x_{i} \leq t<x_{i+1} \\
0, t<x_{i} \vee t \geq x_{i+1}
\end{array}\right.
\end{aligned} \quad \begin{aligned}
k \geq 2: \quad \varphi_{i, k}(t)= & \frac{\left(t-x_{i}\right) \varphi_{i, k-1}(t)}{x_{i+k-1}-x_{i}}+ \\
& +\frac{\left(x_{i+k}-t\right) \varphi_{i+1, k-1}(t)}{x_{i+k}-x_{i+1}} .
\end{aligned}
$$

We will consider such a construction for the case $x_{i}$ $=i$ are integers. Let us note that,

$$
\varphi_{i, k}(t)=\varphi_{0, k}(t-i)
$$

and therefore, recursive formulas (2.1)-(2.2) can be represented in the form

$$
\begin{aligned}
& k=1: \quad \varphi_{0,1}(t)=\left\{\begin{array}{lr}
1, & 0 \leq t<1 \\
0, & t<0 \vee t \geq 1
\end{array},\right. \\
& k \geq 2: \varphi_{0, k}(t)=\frac{1}{k-1}\left[t \cdot \varphi_{0, k-1}(t)+\right. \\
& \left.+(k-t) \varphi_{0, k-1}(t-1)\right] \text {. }
\end{aligned}
$$

The function $\varphi_{0,1}(t)$ can be represented by formula

$$
\varphi_{0,1}(t)=\frac{1}{2}[\operatorname{sign}(t)-\operatorname{sign}(t-1)] .
$$

Let us denote by $\Delta_{1}$ the operator of the first difference. Then we have

$$
\varphi_{0,1}(t)=-\frac{1}{2} \Delta_{1} \operatorname{sign}(t) .
$$

We can substitute formula (2.5) into (2.4) in order to determine $\varphi_{0,2}(t)$ :

$$
\begin{gathered}
\varphi_{0,2}(t)=1 \cdot\left[t \cdot \varphi_{0,1}(t)+(2-t) \varphi_{0,1}(t-1)\right]= \\
=\frac{1}{2}\{t \cdot[\operatorname{sign}(t)-\operatorname{sign}(t-1)]+(2-t)[\operatorname{sign}(t-1)-\operatorname{sign}(t-2)]\}= \\
=\frac{1}{2}[t \operatorname{sign}(t)-2(t-1) \operatorname{sign}(t-1)+ \\
(t-2) \operatorname{sign}(t-2)]=\frac{1}{2}[|t|-2|t-1|+|t-2| .
\end{gathered}
$$

Let us denote by $\Delta_{2}$ the operator of the second difference. Then we have

$$
\varphi_{0,2}(t)=\frac{1}{2}\left[|t|-2|t-1|+|t-2|=\frac{1}{2} \Delta_{2}|t-1| .\right.
$$

We can define function $\varphi_{0,3}(t)$ :

$$
\varphi_{0,3}(t)=\frac{1}{2}\left[t \cdot \varphi_{0,2}(t)+(3-t) \varphi_{0,2}(t-1)\right] .
$$

Omitting intermediate calculations, we get

$$
\begin{array}{r}
\varphi_{0,3}(t)=\frac{1}{4}[t \cdot|t|-3(t-1)|t-1|+ \\
+3(t-2)|t-2|-(t-3)|t-3|]= \\
=-\frac{1}{2} \frac{1}{2} \Delta_{1} \Delta_{2}((t-1)|t-1|) .
\end{array}
$$

Based on formulas (2.8) and (2.4), we can define the function

$$
\varphi_{0,4}(t)=\frac{1}{3}\left[t \cdot \varphi_{0,3}(t)+(4-t) \varphi_{0,3}(t-1)\right] .
$$

Omitting intermediate calculations, we get

$$
\begin{aligned}
& \varphi_{0,4}(t)= \\
& =\frac{1}{2 \cdot 3} \cdot \frac{1}{2}\left[t^{2} \cdot|t|-4(t-1)^{2}|t-1|+\right. \\
& +6(t-2)^{2}|t-2|-4(t-3)^{2}|t-3|+ \\
& \left.+(t-4)^{2}|t-4|\right]= \\
& \quad=\frac{1}{3 !} \frac{1}{2}\left(\Delta_{2}\right)^{2}\left((t-2)^{2}|t-2|\right) .
\end{aligned}
$$

It can be proved that for even $k=2 m$ we have

$\varphi_{0, k}(t)=\frac{1}{(2 m-1) !} \frac{1}{2}\left(\Delta_{2}\right)^{m}\left((t-m)^{2 m-2}|t-m|\right)$

and for odd (uneven) $k=2 m+1$ we have

$$
\varphi_{0, k}(t)=-\frac{1}{(2 m) !} \frac{1}{2} \Delta_{1}\left(\Delta_{2}\right)^{m}\left((t-m)^{2 m-1}|t-1|\right) .
$$

Note that $\varphi_{0, k}(t)$ is a polynomial of degree $k-1$ with bounded support and, as follows from the difference operator, this support is equal to the interval $[0, k]$. In addition, we should note the following property of B-spline basis functions:

$$
\sum_{i} \varphi_{0, k}(t-i) \equiv 1 \text { for arbitrary } t
$$

\section{LOCAL CONSTRUCTIONS FOR ARBITRARY FINITE ELEMENT}

Let us introduce local coordinates:

$$
t=\frac{x-x_{1\left(i_{e}\right)}}{h_{e}}, x_{1\left(i_{e}\right)} \leq x \leq x_{6\left(i_{e}\right)}, 0 \leq t \leq 1 .
$$

In this case, we have the following relations: 
Numerical Solution of the Problem of Beam Analysis With the Use of B-Spline Finite Element Method

$$
\begin{aligned}
& \left\{\begin{array}{l}
x=x_{1\left(i_{e}\right)} \Rightarrow t=0 \\
x=x_{2} \Rightarrow t=0.2 \\
x=x_{3} \Rightarrow t=0.4 \\
x=x_{4} \Rightarrow t=0.6 \\
x=x_{5} \Rightarrow t=0.8 \\
x=x_{6\left(i_{e}\right)} \Rightarrow t=1
\end{array}\right. \\
& \frac{d}{d x}=\frac{d}{d t} \cdot \frac{d t}{d x}=\frac{1}{h_{e}} \frac{d}{d t}, d x=h_{e} \cdot d t . \\
& \frac{d^{p}}{d x^{p}}=\frac{1}{h_{e}^{p}} \frac{d^{p}}{d t^{p}},
\end{aligned}
$$

Since the number of unknowns on the element is equal to $N=8$, we use a B-spline of the seventh degree in order to represent the unknown deflection function. Let us use the following notation:

$$
\begin{gathered}
\varphi(t)=\varphi_{0,8}(t+4) ; \\
\varphi(t)=\frac{1}{7 !} \frac{1}{2}\left(\Delta_{2}\right)^{4}\left(t^{6}|t|\right)= \\
=\frac{1}{2 \cdot 7 !}\left[(t+4)^{6}|t+4|-\right. \\
-8(t+3)^{6}|t+3|+ \\
+28(t+2)^{6}|t+2|- \\
-56(t+1)^{6}|t+1|+70 t^{6}|t|- \\
-56(t-1)^{6}|t-1|+28(t-2)^{6}|t-2|- \\
\left.-8(t-3)^{6}|t-3|+(t-4)^{6}|t-4|\right] .
\end{gathered}
$$

This function is a B-spline, symmetric with respect to $t=0$ and its support is defined by an interval $[-4$, 4] (Figure 2).

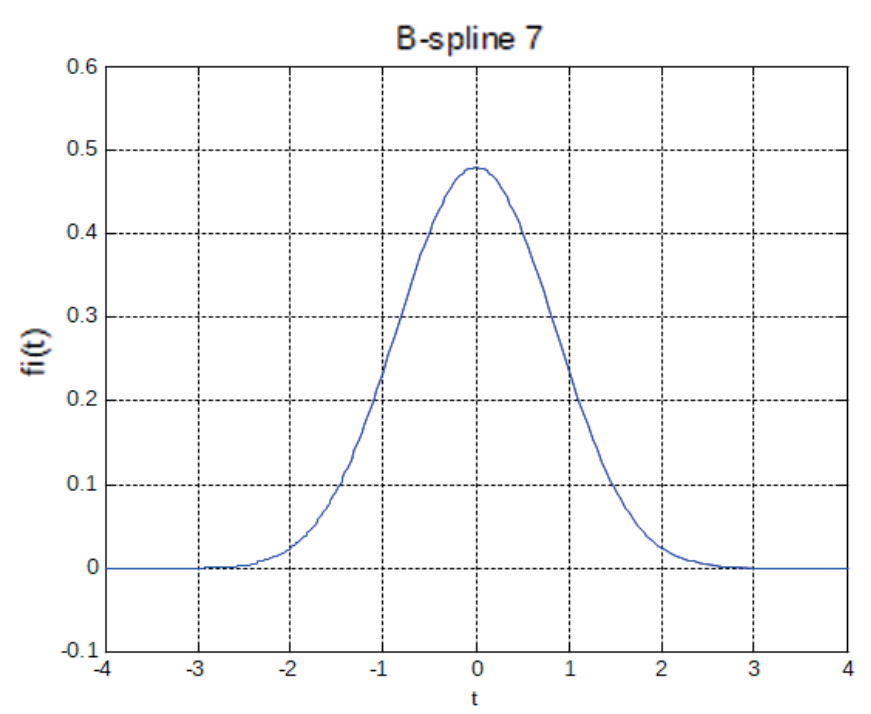

Figure 2. B-spline of the seventh order $\varphi(t)=\varphi_{0.8}(t+4)$.
Let us use the following notation system:

$$
\begin{gathered}
\varphi_{1}(t)=\varphi(t+3), \varphi_{2}(t)=\varphi(t+2), \\
\varphi_{3}(t)=\varphi(t+1), \varphi_{4}(t)=\varphi(t), \\
\varphi_{5}(t)=\varphi(t-1), \\
\varphi_{6}(t)=\varphi(t-2), \varphi_{7}(t)=\varphi(t-3), \\
\varphi_{8}(t)=\varphi(t-4), 0 \leq t \leq 1 .
\end{gathered}
$$

We represent the unknown deflection function in the form

$$
\begin{aligned}
& y(x)=w(t)=\sum_{k=1}^{N} \alpha_{k} \varphi_{k}(t), \\
& x_{1\left(i_{e}\right)} \leq x \leq x_{6\left(i_{e}\right)}, 0 \leq t \leq 1 .
\end{aligned}
$$

We can substitute (3.4) into (1.3), taking into account relations (3.1).

$$
\begin{aligned}
\Phi_{i_{e}} & (y)=\frac{1}{2} \int_{x_{1}\left(i_{e}\right)}^{x_{\sigma}\left(i_{e}\right)}\left(E J\left(\frac{d^{2} y}{d x^{2}}\right)^{2}+\beta y^{2}\right) d x-\int_{x_{1}\left(i_{e}\right)}^{x_{\sigma}\left(i_{e}\right)} q y d x= \\
= & \frac{1}{2} \int_{0}^{1}\left(\frac{E J}{h_{e}^{3}}\left(w^{\prime \prime}\right)^{2}+\beta h_{e} w^{2}\right) d t-\int_{0}^{1} h_{e} q w d t= \\
& =\frac{1}{2} \sum_{i=1}^{N} \sum_{j=1}^{N} \alpha_{i} \alpha_{j} \times \\
& \times \int_{0}^{1}\left(\frac{E J}{h_{e}^{3}}\left(\varphi^{\prime \prime}(t) \varphi_{j}^{\prime \prime}(t)\right)+\beta h_{e}\left(\varphi_{i}(t) \varphi_{j}(t)\right)\right) d t- \\
& -\sum_{i=1}^{N} \alpha_{i} \int_{0}^{1} h_{e} q \varphi_{i}(t) d t= \\
& =\frac{1}{2}\left(K_{\alpha}^{i_{e}} \bar{\alpha}, \bar{\alpha}\right)-\left(\bar{R}_{\alpha}^{i_{e}}, \bar{\alpha}\right)=\Phi_{\alpha}(\bar{\alpha}),
\end{aligned}
$$

where we have

$$
\begin{gathered}
K_{\alpha}^{i_{e}}(i, j)= \\
\int_{0}^{1}\left(\frac{E J}{h_{e}^{3}}\left(\varphi_{i}^{\prime \prime}(t) \varphi_{j}^{\prime \prime}(t)\right)+\beta h_{e}\left(\varphi_{i}(t) \varphi_{j}(t)\right)\right) d t ; \\
R_{\alpha}^{i_{e}}(i)=\int_{0}^{1}\left(h_{e} q(t) \varphi_{i}(t)\right) d t .
\end{gathered}
$$

Let's define the parameters through the nodal unknowns on the element: 


$$
\left\{\begin{aligned}
y_{1} & =w(0)=\sum_{k=1}^{N} \alpha_{k} \varphi_{k}(0) \\
\frac{d y_{1}}{d x} & =\frac{1}{h_{e}} w^{\prime}(0)=\frac{1}{h_{e}} \sum_{k=1}^{N} \alpha_{k} \varphi_{k}^{\prime}(0) \\
y_{2} & =w(0.2)=\sum_{k=1}^{N} \alpha_{k} \varphi_{k}(0.2) \\
y_{3} & =w(0.4)=\sum_{k=1}^{N} \alpha_{k} \varphi_{k}(0.4) \\
y_{4} & =w(0.6)=\sum_{k=1}^{N} \alpha_{k} \varphi_{k}(0.6) \\
y_{5} & =w(0.8)=\sum_{k=1}^{N} \alpha_{k} \varphi_{k}(0.8) \\
y_{6} & =w(1)=\sum_{k=1}^{N} \alpha_{k} \varphi_{k}(1) \\
\frac{d y_{6}}{d x} & =\frac{1}{h_{e}} w^{\prime}(1)=\frac{1}{h_{e}} \sum_{k=1}^{N} \alpha_{k} \varphi_{k}^{\prime}(1)
\end{aligned}\right.
$$

Therefor we have

$$
\bar{y}^{i_{e}}=T \alpha
$$

where

$$
\begin{aligned}
& \bar{y}^{i_{e}}=\left[\begin{array}{llllllll}
y_{1} & \frac{d y_{1}}{d x} & y_{2} & y_{3} & y_{4} & y_{5} & y_{6} & \frac{d y_{6}}{d x}
\end{array}\right]^{\mathrm{T}} ; \\
& \bar{\alpha}=\left[\begin{array}{llllllll}
\alpha_{1} & \alpha_{2} & \alpha_{3} & \alpha_{4} & \alpha_{5} & \alpha_{6} & \alpha_{7} & \alpha_{8}
\end{array}\right]^{\mathrm{T}} \quad ;
\end{aligned}
$$

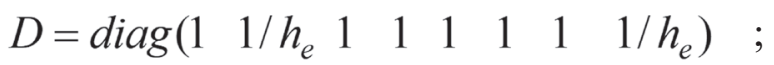$$
T=D\left[\begin{array}{cccccccc}
\varphi_{1}(0) & \varphi_{2}(0) & \varphi_{3}(0) & \varphi_{4}(0) & \varphi_{5}(0) & \varphi_{6}(0) & \varphi_{7}(0) & \varphi_{8}(0) \\
\varphi_{1}^{\prime}(0) & \varphi_{2}^{\prime}(0) & \varphi_{3}^{\prime}(0) & \varphi_{4}^{\prime}(0) & \varphi_{5}^{\prime}(0) & \varphi_{6}^{\prime}(0) & \varphi_{7}^{\prime}(0) & \varphi_{8}^{\prime}(0) \\
\varphi_{1}(0.2) & \varphi_{2}(0.2) & \varphi_{3}(0.2) & \varphi_{4}(0.2) & \varphi_{5}(0.2) & \varphi_{6}(0.2) & \varphi_{7}(0.2) & \varphi_{8}(0.2) \\
\varphi_{1}(0.4) & \varphi_{2}(0.4) & \varphi_{3}(0.4) & \varphi_{4}(0.4) & \varphi_{5}(0.4) & \varphi_{6}(0.4) & \varphi_{7}(0.4) & \varphi_{8}(0.4) \\
\varphi_{1}(0.6) & \varphi_{2}(0.6) & \varphi_{3}(0.6) & \varphi_{4}(0.6) & \varphi_{5}(0.6) & \varphi_{6}(0.6) & \varphi_{7}(0.6) & \varphi_{8}(0.6) \\
\varphi_{1}(0.8) & \varphi_{2}(0.8) & \varphi_{3}(0.8) & \varphi_{4}(0.8) & \varphi_{5}(0.8) & \varphi_{6}(0.8) & \varphi_{7}(0.8) & \varphi_{8}(0.8) \\
\varphi_{1}(1) & \varphi_{2}(1) & \varphi_{3}(1) & \varphi_{4}(1) & \varphi_{5}(1) & \varphi_{6}(1) & \varphi_{7}(1) & \varphi_{8}(1) \\
\varphi_{1}^{\prime}(1) & \varphi_{2}^{\prime}(1) & \varphi_{3}^{\prime}(1) & \varphi_{4}^{\prime}(1) & \varphi_{5}^{\prime}(1) & \varphi_{6}^{\prime}(1) & \varphi_{7}^{\prime}(1) & \varphi_{8}^{\prime}(1)
\end{array}\right]
$$

Substituting (3.7) into $\Phi_{\alpha}(\bar{\alpha})$, we obtain

where

$$
K^{i_{e}}=\left(T^{-1}\right)^{\mathrm{T}} K_{\alpha}^{i_{e}} T^{-1}
$$

is the local stiffness matrix;

$$
\bar{R}^{i_{e}}=\left(T^{-1}\right)^{\mathrm{T}} \bar{R}_{\alpha}^{i_{e}}
$$

is the local load vector.

$$
\begin{aligned}
& \Phi_{\alpha}(\bar{\alpha})= \\
& =\frac{1}{2}\left(K_{\alpha}^{i_{e}} T^{-1} \bar{y}^{i_{e}}, T^{-1} \bar{y}^{i_{e}}\right)-\left(\bar{R}_{\alpha}^{i_{e}}, T^{-1} \bar{y}^{i_{e}}\right)= \\
& =\frac{1}{2}\left(\left(T^{-1}\right)^{\mathrm{T}} K_{\alpha}^{i_{e}} T^{-1} \bar{y}^{i_{e}}, \bar{y}^{i_{e}}\right)-\left(\left(T^{-1}\right)^{\mathrm{T}} \bar{R}_{\alpha}^{i_{e}}, \bar{y}^{i_{e}}\right)= \\
& =\frac{1}{2}\left(K^{i_{e}} \bar{y}^{i_{e}}, \bar{y}^{i_{e}}\right)-\left(\bar{R}^{i_{e}}, \bar{y}^{i_{e}}\right)=\Phi_{i_{e}}\left(\bar{y}^{i_{e}}\right),
\end{aligned}
$$




\section{INFORMATION ABOUT NUMERICAL IMPLEMENTATION}

The presented algorithm can be implemented using MATLAB tools. The MATLAB system has convenient functions for working with polynomials. Moreover, the main parameter of these functions is the vector of coefficients of the polynomial. To determine the coefficients of basic polynomials $\varphi_{k}$ on an interval $\left[\begin{array}{ll}0 & 1\end{array}\right]$, we can firstly determine their values at eight points of the interval $t=\left[t_{1}, t_{2}, \ldots, t_{8}\right], t_{i} \in\left[\begin{array}{ll}0 & 1\end{array}\right]$, $i=1,2, \ldots, 8$;

$$
\begin{gathered}
F_{k}(i)=\varphi_{k}\left(t_{i}\right), i=1,2, \ldots, 8, \\
k=1,2, \ldots, 8 .
\end{gathered}
$$

Then, using the polyfit function, we define their coefficient vector:

$$
\mathrm{pk}=\operatorname{pol} \mathrm{yfit}_{(t, F k, 7)}
$$

This function is used to determine the coefficients of the optimal polynomial using the least squares method. In the considering case, we are looking for a polynomial of the 7 th degree (i.e. we have to define 8 coefficients of polynomial, according to its 8 values), therefore, we get a polynomial passing through the given values.

In order to calculate the derivatives we can sequentially use the polyder function:

$$
\mathrm{dpk}=\mathrm{pol} \text { yder }(\mathrm{pk})
$$

is the vector of coefficients $\varphi_{k}^{\prime}$;

$\mathrm{d} 2 \mathrm{pk}=\mathrm{pol}$ yder $(\mathrm{dpk})$

is the vector of coefficients $\varphi_{k}^{\prime \prime}$.

In order to calculate the product of polynomials we can use the conv function:

$$
p i j=\operatorname{conv}(p i, p j)
$$

is the vector of coefficients $\varphi_{i} \varphi_{j}$; $\mathrm{d} 2 \mathrm{pi} j=\mathrm{conv}(\mathrm{d} 2 \mathrm{pi}, \mathrm{d} 2 \mathrm{pj})$ is the vector of coefficients $\varphi_{i}^{\prime \prime} \varphi_{j}^{\prime \prime}$.

In order to calculate the antiderivative of a polynomial we can use the polyint function:

$$
\mathrm{Pi}=\mathrm{polyint}(\mathrm{pi})
$$

is the vector of coefficients $\int \varphi_{i} d t$;

Pij=polyint (pij)

is the vector of coefficients $\int \varphi_{i} \varphi_{j} d t$;

$\mathrm{d} 2 \mathrm{Pij}=\mathrm{polyint}(\mathrm{d} 2 \mathrm{pij})$

is the vector of coefficients $\int \varphi_{i}^{\prime \prime} \varphi_{j}^{\prime \prime} d t$.

Then the calculation (formula (3.5))

$$
\begin{aligned}
& K_{\alpha}^{i_{e}}(i, j)= \\
& =\int_{0}^{1}\left(\frac{E J}{h_{e}^{3}}\left(\varphi_{i}^{\prime \prime}(t) \varphi_{j}^{\prime \prime}(t)\right)+\beta h_{e}\left(\varphi_{i}(t) \varphi_{j}(t)\right)\right) d t .
\end{aligned}
$$

can be summarized as follows:

$$
\begin{gathered}
K_{\alpha}^{i_{e}}(i, j)=\frac{E J}{h_{e}^{3}}(\operatorname{polyval}(\mathrm{d} 2 \mathrm{Pij}, 1)- \\
\operatorname{polyval}(\mathrm{d} 2 \mathrm{P} i j, 0))+ \\
+\beta h_{e}(\operatorname{polyval}(\operatorname{Pij}, 1)- \\
\operatorname{polyval}(\operatorname{Pij}, 0)),
\end{gathered}
$$

where the function polyval (, , t ) allows researcher to calculate the values of a polynomial with a vector of coefficients $p$ at a given point $t$.

As for the calculation (see (3.5)),

$$
R_{\alpha}^{i_{e}}(i)=\int_{0}^{1}\left(h_{e} q(t) \varphi_{i}(t)\right) d t
$$

here, for example, the following options are possible: - point load setting (using delta functions); - setting the load averaged on the element,

$$
\begin{aligned}
R_{\alpha}^{i_{e}}(i) & =h_{e} q_{i e}(\operatorname{polyval}(\mathrm{Pi}, 1)- \\
& -\operatorname{polyval}(\mathrm{Pi}, 0))
\end{aligned}
$$

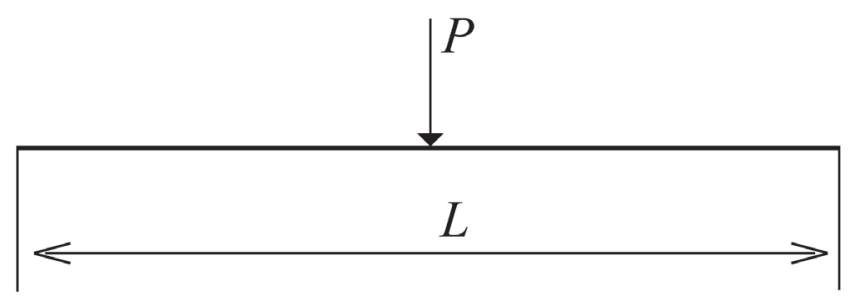

Figure 3. Example of analysis.

If $q$ is represented by a polynomial, then, as in the case of calculating the elements of a local matrix $K_{\alpha}^{i_{e}}$, here researcher can use the function of multiplying polynomials conv followed by determining the antiderivative of the product using the polyint functions and calculating the definite integral using the polyval function. 


\section{EXAMPLE OF ANALYSIS}

As a model example let us consider a beam on an elastic foundation with the following parameters:

$$
q(x)=P \delta\left(x-\frac{L}{2}\right), P=100 \mathrm{kN}
$$

is load given at the midpoint (Figure 3);

$$
\begin{gathered}
L=8 m ; h_{b}=1.3 m ; b_{b}=1 m ; \\
E=2560 \cdot 10^{4} \mathrm{kN} / \mathrm{m}^{2} ; k=75 \cdot 10^{3} \mathrm{kN} / \mathrm{m}^{3} .
\end{gathered}
$$

In this case we should consider the following boundary conditions:

$$
\left\{\begin{array}{l}
y(0)=y^{\prime \prime}(0)=0 \\
y(L)=y^{\prime \prime}(L)=0
\end{array}\right.
$$

- the beam is hingedly supported on both sides (the first case);

$$
\left\{\begin{array}{l}
y(0)=y^{\prime}(0)=0 \\
y(L)=y^{\prime}(L)=0
\end{array}\right.
$$

- the beam is rigidly fixed on both sides (the second case);

$$
\left\{\begin{array}{l}
y(0)=y^{\prime \prime}(0)=0 \\
y^{\prime \prime \prime}(L)=y^{\prime \prime}(L)=0
\end{array}\right.
$$

- the beam is hingedly supported on the left end, the right end is free (the third case);

$$
\left\{\begin{array}{l}
y(0)=y^{\prime}(0)=0 \\
y^{\prime \prime \prime}(L)=y^{\prime \prime}(L)=0
\end{array}\right.
$$

the beam is rigidly fixed to the left end, the right end is free (the fourth case).

Let us set $N_{e}=4$ (the number of elements).

Then we have

$$
N_{g}=N_{p}+2 N_{b}=4 \cdot(5-1)+2 \cdot(4+1)=26 ;
$$

is the total number of unknowns;

$$
h_{e}=L / N_{e}=8 / 4=2
$$

is the length of the element;

$$
h_{p}=h_{e} / 5=2 / 5=0.4
$$

Figures 5. Comparison of results for the second case.

is the total number of nodes.

Several results of analysis are presented at Figures 4, 5, 6 and 7.

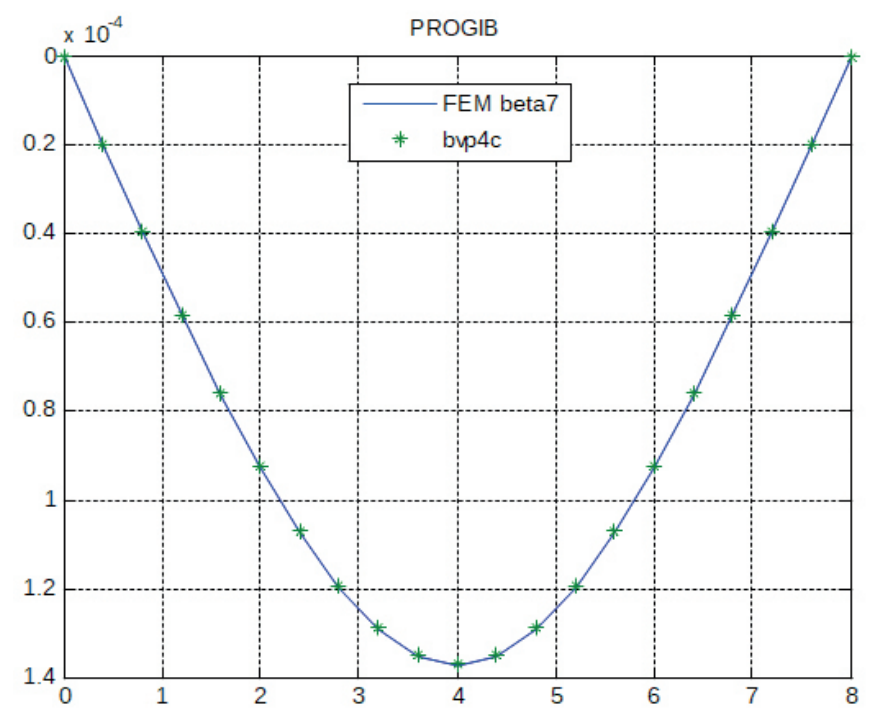

Figures 4. Comparison of results for the first case.

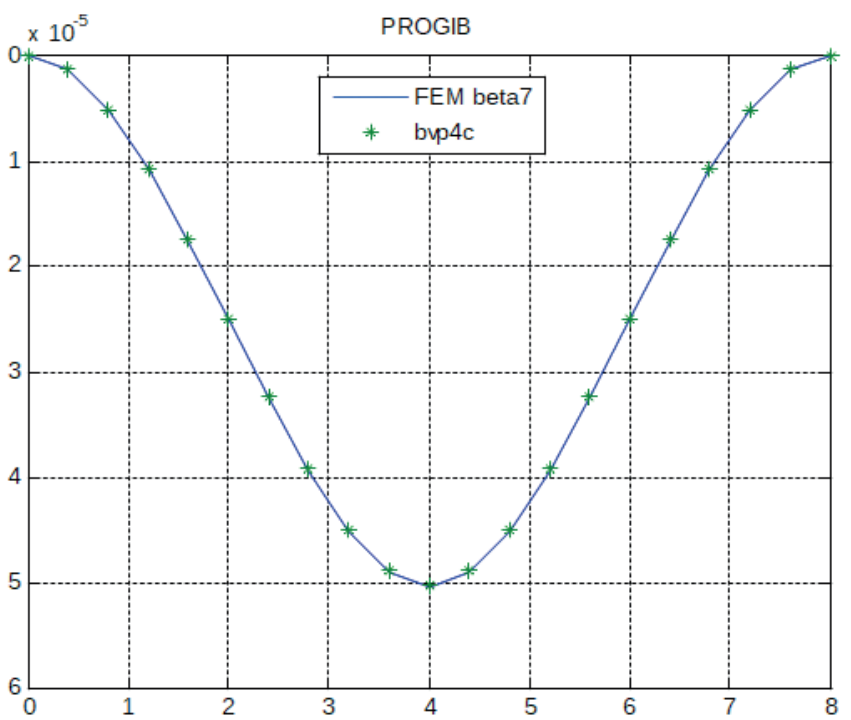

is the step between the coordinates of the nodes;

$$
N_{x}=L / h_{p}+1=8 / 0.4+1=21
$$




\section{ACKNOWLEDGEMENTS}

The distinctive research work was carried out at the expense of the State program of the Russian Federation "Scientific and technological development of the Russian Federation" and the Program for Fundamental Research of State Academies of Science for 2013-2020, as part of the Plan for Fundamental

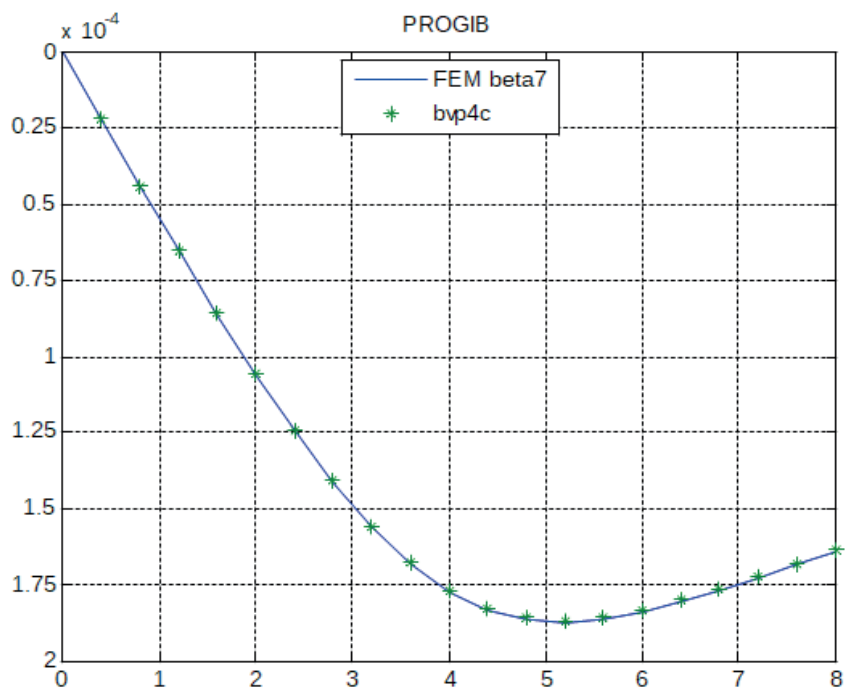

Figures 6. Comparison of results for the third case.

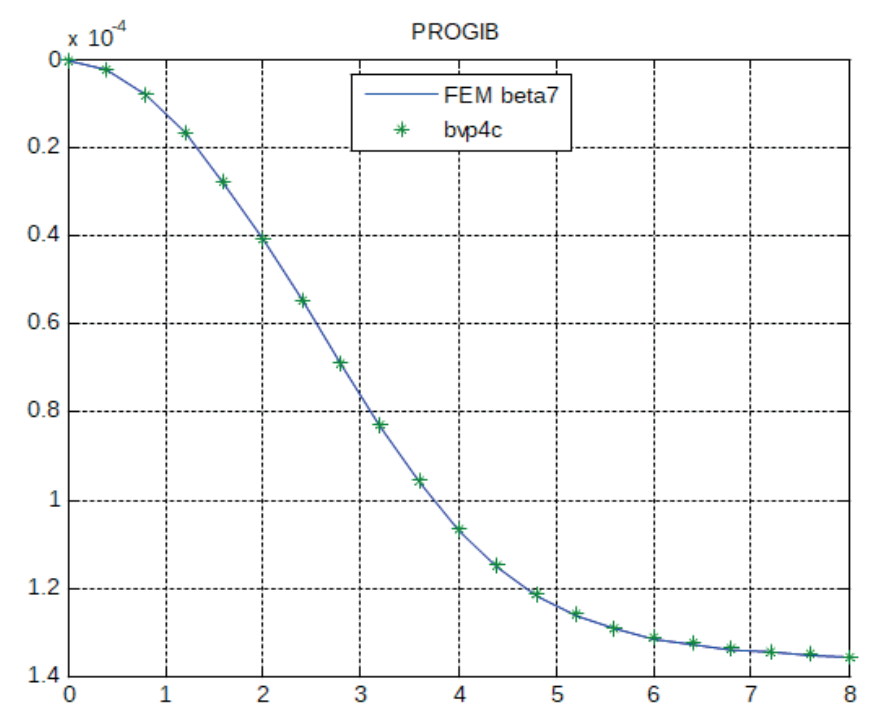

Figures 7. Comparison of results for the fourth case.
Scientific Research of the Ministry of Construction and Housing and Communal Services of the Russian Federation and the Russian Academy of Architecture and Construction Sciences for 2020, within science topic "Research and development of fundamental theoretical foundations of the synthesis of optimal structures as methods for designing structures with predetermined properties".

\section{REFERENCES}

1. Li B., Chen X. Wavelet-based numerical analysis: A review and classification. // Finite Elements in Analysis and Design, 2014, Vol. 81, pp. 14-31.

2. Daubechies I. Orthonormal bases of compactly supported wavelets. // Commun. Pure Appl. Math., 1988, Vol. 41, pp. 909-996.

3. Li B., Cao H.R., He Z.J. The construction of one-dimensional Daubechies wavelet-based finite elements for structural response analysis. // J. Vibroeng, 2011, vol. 13, pp. 729-738.

4. Ma J.R., Xue J.J. A study of the construction and application of a Daubechies wave-let-based beam element. // Finite Elements in Analysis and Design, 2003, Vol. 39, pp. 965-975.

5. Mozgaleva M.L., Akimov P.A., Kaytukov T.B. About wavelet-based computational beam analysis with the use of Daubechies scaling functions. // International Journal for Computational Civil and Structural Engineering, 2019, Vol. 15, Issue 2, pp. 95-110.

6. Mozgaleva M.L., Akimov P.A., Kaytukov T.B. Wavelet-based discrete-continual finite element plate analysis with the use of Daubechies scaling functions. // International Journal for Computational Civil and Structural Engineering, 2019, Vol. 15, Issue 3, pp. 96-108.

7. Antes H. Bicubic fundamental splines in plate bending. // Int. J. Numer. Methods Eng., 1974, Vol. 8, pp. 503-511.

8. Han J.G., Ren W.X., Huang Y. A spline wavelet finite-element method in structural mechanics. // Int. J. Numer. Methods Eng., 2006, Vol. 66, pp. 166-190.

9. Han J.G., Ren W.X., Huang Y. A spline wavelet finite element formulation of thin plate bending. // Eng. Comput., 2009, Vol. 25, pp. 319-326. 
10. Xiang J.W., Chen X.F., He Z.J., Zhang Y.H. A new wavelet-based thin plate element using B-spline wavelet on the interval. // Comput. Math., 2008, Vol. 41, pp. 243-255.

11. Chen X.F., Xiang J.W., Li B., He Z.J. A study of multiscale wavelet-based elements for adaptive finite element analysis. // Adv. Eng. Softw., 2010, Vol. 41, pp. 196-205.

12. Zhong Y.T., Xiang J.W. Construction of waveletbased elements for static and stability analysis of elastic problems. // Acta Mech. Solida Sin., 2011, Vol. 24, pp. 355-364.

13. Yang Z.B., Chen X.F., Li B., He Z.J., Miao H.H. Vibration analysis of curved shell using b-spline wavelet on the interval (BSWI). // Finite Elements Method and General Shell Theory, CMES85, 2012, pp. 129-155.

14. Yang Z.B., Chen X.F., Zhang X.W., He Z.J. Free vibration and buckling analysis of plates using B-spline wavelet on the interval Mindlin element. // Appl. Math. Model., 2013, Vol. 37, pp. 3449-3466.

15. Xiang J.W., Chen X.F., Li B., He Y.M., He Z.J. Identification of a crack in a beam based on the finite element method of a B-spline wavelet on the interval. // J. Sound Vibr., 2006, Vol. 296, pp. 1046-1052.

16. Xiang J.W., Chen X.F., Mo Q.M., He Z.H. Identification of crack in a rotor system based on wavelet finite element method. // Finite Elem. Anal. Des., 2007, Vol. 43, pp. 1068-1081.

17. Xiang J.W., Liang M. A two-step approach to multi-damage detection for plate structures. // Eng. Fract. Mech., 2012, Vol. 91, pp. 73-86.

18. Xiang J.W., Matsumoto T., Long J.Q., Ma G. Identification of damage locations based on operating deflection shape. // Nondestruct. Test. Eval., 2012, Vol. 1, pp. 1-15.

19. Xiang J.W., Liang M. Wavelet-based detection of beam cracks using modal shape and frequency measurements. // Comput.-Aided Civil Infrastruct. Eng., 2012, Vol. 27, pp. 439-454.

20. Xiang J.W., Matsumoto T., Wang Y.W., Jiang Z.S. Detect damages in conical shells using curvature mode shape and wavelet finite element method. // Int. J. Mech. Sci., 2013, Vol. 66, pp. 83-93.

21. Dong H.B., Chen X.F., Li B., Qi K.Y., He Z.J. Rotor crack detection based on high-precision modal parameter identification method and wavelet finite element model. // Mech. Syst. Signal Process., 2009, Vol. 23, pp. 869-883.

22. Chen X.F., Yang Z.B., Zhang X.W., He Z.J. Modeling of wave propagation in one-dimension structures using B-spline wavelet on interval finite element. // Finite Elem. Anal. Des., 2012, Vol. 51, pp. 1-9.

23. Han J.G., Ren W.X., Huang Y. A multivariable wavelet-based finite element method and its application to thick plates. // Finite Elem. Anal. Des., 2005, Vol. 41, pp. 821-833.

24. Zhang X.W., Chen X.F., He Z.J. The analysis of shallow shells based on multivariable wavelet finite element method. // Acta Mech. Solida Sin., 2011, Vol. 24, pp. 450-460.

25. Han J.G., Ren W.X., Huang Y. A wavelet-based stochastic finite element method of thin plate bending. // Appl. Math. Model., 2007, Vol. 31, pp. 181-193.

26. Pian T.H.H., Chen D.P. Alternative ways for formulation of hybrid stress elements. // Int. J. Numer. Methods Eng., 1982, Vol. 18, pp. 1679-1684.

27. Pian T.H.H., Sumihara K. Rational approach for assumed stress finite elements. // Int. J. Numer. Methods Eng., 1984, Vol. 20, pp. 1685-1695.

28. Mau S.T., Tong P., Pian T.H.H. Finite element solutions for laminated thick plates. // J. Compos. Mater., 1972, Vol. 6, pp. 304-311.

29. Akimov P.A., Aslami M. About verification of correct wavelet-based approach to local static analysis of Bernoulli beam. // Applied Mechanics and Materials, 2014, Vols. 580-583, pp. 3013-3016.

30. Akimov P.A., Aslami M. Theoretical foundations of correct wavelet-based approach to local static analysis of Bernoulli beam. // Applied Mechanics and Materials, 2014, Vols. 580-583, pp. 29242927.

31. Aslami M., Akimov P.A. Analytical solution for beams with multipoint boundary conditions on two-parameter elastic foundation. // Archives of Civil and Mechanical Engineering, 2016, Vol. 16, Issue 4, pp. 668-677. 


\section{СПИСОК ЛИТЕРАТУРЫ}

1. Li B., Chen X. Wavelet-based numerical analysis: A review and classification. // Finite Elements in Analysis and Design, 2014, Vol. 81, pp. 14-31.

2. Daubechies I. Orthonormal bases of compactly supported wavelets. // Commun. Pure Appl. Math., 1988, Vol. 41, pp. 909-996.

3. Li B., Cao H.R., He Z.J. The construction of one-dimensional Daubechies wavelet-based finite elements for structural response analysis. // J. Vibroeng, 2011, vol. 13, pp. 729-738.

4. Ma J.R., Xue J.J. A study of the construction and application of a Daubechies wave-let-based beam element. // Finite Elements in Analysis and Design, 2003, Vol. 39, pp. 965-975.

5. Mozgaleva M.L., Akimov P.A., Kaytukov T.B. About wavelet-based computational beam analysis with the use of Daubechies scaling functions. // International Journal for Computational Civil and StructuralEngineering,2019, Vol.15, Issue2,pp.95-110.

6. Mozgaleva M.L., Akimov P.A., Kaytukov T.B. Wavelet-based discrete-continual finite element plate analysis with the use of Daubechies scaling functions. // International Journal for Computational Civil and Structural Engineering, 2019, Vol. 15, Issue 3, pp. 96-108.

7. Antes H. Bicubic fundamental splines in plate bending. // Int. J. Numer. Methods Eng., 1974, Vol. 8, pp. 503-511.

8. Han J.G., Ren W.X., Huang Y. A spline wavelet finite-element method in structural mechanics. // Int. J. Numer. Methods Eng., 2006, Vol. 66, pp. 166-190.

9. Han J.G., Ren W.X., Huang Y. A spline wavelet finite element formulation of thin plate bending. // Eng. Comput., 2009, Vol. 25, pp. 319-326.

10. Xiang J.W., Chen X.F., He Z.J., Zhang Y.H. A new wavelet-based thin plate element using B-spline wavelet on the interval. // Comput. Math., 2008, Vol. 41, pp. 243-255.

11. Chen X.F., Xiang J.W., Li B., He Z.J. A study of multiscale wavelet-based elements for adaptive finite element analysis. // Adv. Eng. Softw., 2010, Vol. 41, pp. 196-205.

12. Zhong Y.T., Xiang J.W. Construction of waveletbased elements for static and stability analysis of elastic problems. // Acta Mech. Solida Sin., 2011, Vol. 24, pp. 355-364.
13. Yang Z.B., Chen X.F., Li B., He Z.J., Miao H.H. Vibration analysis of curved shell using b-spline wavelet on the interval (BSWI). // Finite Elements Method and General Shell Theory, CMES85, 2012, pp. 129-155.

14. Yang Z.B., Chen X.F., Zhang X.W., He Z.J. Free vibration and buckling analysis of plates using B-spline wavelet on the interval Mindlin element. // Appl. Math. Model., 2013, Vol. 37, pp. 3449-3466.

15. Xiang J.W., Chen X.F., Li B., He Y.M., He Z.J. Identification of a crack in a beam based on the finite element method of a B-spline wavelet on the interval. // J. Sound Vibr., 2006, Vol. 296, pp. 1046-1052.

16. Xiang J.W., Chen X.F., Mo Q.M., He Z.H. Identification of crack in a rotor system based on wavelet finite element method. // Finite Elem. Anal. Des., 2007, Vol. 43, pp. 1068-1081.

17. Xiang J.W., Liang M. A two-step approach to multi-damage detection for plate structures. // Eng. Fract. Mech., 2012, Vol. 91, pp. 73-86.

18. Xiang J.W., Matsumoto T., Long J.Q., Ma G. Identification of damage locations based on operating deflection shape. // Nondestruct. Test. Eval., 2012, Vol. 1, pp. 1-15.

19. Xiang J.W., Liang M. Wavelet-based detection of beam cracks using modal shape and frequency measurements. // Comput.-Aided Civil Infrastruct. Eng., 2012, Vol. 27, pp. 439-454.

20. Xiang J.W., Matsumoto T., Wang Y.W., Jiang Z.S. Detect damages in conical shells using curvature mode shape and wavelet finite element method. // Int. J. Mech. Sci., 2013, Vol. 66, pp. 83-93.

21. Dong H.B., Chen X.F., Li B., Qi K.Y., He Z.J. Rotor crack detection based on high-precision modal parameter identification method and wavelet finite element model. // Mech. Syst. Signal Process., 2009, Vol. 23, pp. 869-883.

22. Chen X.F., Yang Z.B., Zhang X.W., He Z.J. Modeling of wave propagation in one-dimension structures using B-spline wavelet on interval finite element. // Finite Elem. Anal. Des., 2012, Vol. 51, pp. 1-9.

23. Han J.G., Ren W.X., Huang Y. A multivariable wavelet-based finite element method and its application to thick plates. // Finite Elem. Anal. Des., 2005, Vol. 41, pp. 821-833. 
24. Zhang X.W., Chen X.F., He Z.J. The analysis of shallow shells based on multivariable wavelet finite element method. // Acta Mech. Solida Sin., 2011, Vol. 24, pp. 450-460.

25. Han J.G., Ren W.X., Huang Y. A wavelet-based stochastic finite element method of thin plate bending. // Appl. Math. Model., 2007, Vol. 31, pp. 181-193.

26. Pian T.H.H., Chen D.P. Alternative ways for formulation of hybrid stress elements. // Int. J. Numer. Methods Eng., 1982, Vol. 18, pp. 1679-1684.

27. Pian T.H.H., Sumihara K. Rational approach for assumed stress finite elements. // Int. J. Numer. Methods Eng., 1984, Vol. 20, pp. 1685-1695.

28. Mau S.T., Tong P., Pian T.H.H. Finite element solutions for laminated thick plates. // J. Compos. Mater., 1972, Vol. 6, pp. 304-311.
29. Akimov P.A., Aslami M. About verification of correct wavelet-based approach to local static analysis of Bernoulli beam. // Applied Mechanics and Materials, 2014, Vols. 580-583, pp. 3013-3016.

30. Akimov P.A.,Aslami M. Theoretical foundations of correct wavelet-based approach to local static analysis of Bernoulli beam. // Applied Mechanics and Materials, 2014, Vols. 580-583, pp. 2924 2927.

31. Aslami M., Akimov P.A. Analytical solution for beams with multipoint boundary conditions on two-parameter elastic foundation. // Archives of Civil and Mechanical Engineering, 2016, Vol. 16, Issue 4, pp. 668-677.

Акимов Павел Алексеевич, академик РААСН, профессор, доктор технических наук; временно исполняющий обязанности ректора Национального исследовательского Московского государственного строительного университета; профессор Департамента архитектуры и строительства Российского университета дружбы народов; профессор кафедры строительной механики Томского государственного архитектурно-строительного университета; исполняющий обязанности вице-президента Российской академии архитектуры и строительных наук; 129337, Россия, г. Москва, Ярославское шоссе, дом 26; телефон: +7(495)651-81-85; факс:+7(499)183-44-38; Email: AkimovPA@mgsu.ru, rector@mgsu.ru, pavel.akimov@gmail.com.

Мозгалева Марина Леонидовна, старший научный сотрудник, доктор технических наук; профессор кафедры прикладной математики Национального исследовательского Московского государственного строительного университета; 129337, Россия, г. Москва, Ярославское шоссе, дом 26; телефон/факс: +7(499) 183-59-94; Email: marina.mozgaleva@gmail.com.

Кайтуков Таймураз Батразович, советник РААСН, доцент, кандидат технических наук; проректор, профессор кафедры прикладной математики Национального исследовательского Московского государственного строительного университета; 129337, Россия, г. Москва, Ярославское шоссе, дом 26; телефон: +7(499) 929-52-29; факс: +7(499) 183-44-38; Email: KaytukovTB@mgsu.ru.

Pavel A. Akimov, Full Member of the Russian Academy of Architecture and Construction Sciences, Professor, Dr.Sc.; Acting Rector of National Research Moscow State University of Civil Engineering; Professor of Department of Architecture and Construction, Peoples' Friendship University of Russia; Professor of Department of Structural Mechanics, Tomsk State University of Architecture and Building; Acting Vice-President of the Russian Academy of Architecture and Construction Sciences; 26, Yaroslavskoe Shosse, Moscow, 129337, Russia; phone:+7(495) 651-81-85; Fax:+7(499) 183-44-38; E-mail: AkimovPA@mgsu.ru, rector@mgsu.ru, pavel.akimov@gmail.com.

Marina L. Mozgaleva, Senior Scientist Researcher, Dr.Sc.; Professor of Department of Applied Mathematics, National Research Moscow State University of Civil Engineering; 26, Yaroslavskoe Shosse, Moscow, 129337, Russia; phone/fax +7(499) 183-59-94; Fax: +7(499) 183-44-38; Email: marina.mozgaleva@gmail.com.

Taymuraz B. Kaytukov, Advisor of the Russian Academy of Architecture and Construction Sciences, Associate Professor, Ph.D.; Vice-Rector, Associate Professor Department of Applied Mathematics, National Research Moscow State University of Civil Engineering; 26, Yaroslavskoe Shosse, Moscow, 129337, Russia; phone: +7(499) 929-52-29; fax: +7(499) 183-59-94; Email: KaytukovTB@mgsu.ru. 